\title{
Mineralogical characterization of a highly-weathered soil by the Rietveld Method
}

\author{
André Maurício Brinatti1*; Yvonne Primerano Mascarenhas²; Vitor Paulo Pereira ${ }^{3}$; \\ Carmen Silvia de Moya Partiti ${ }^{4}$; Álvaro Macedo ${ }^{5}$ \\ ${ }^{1}$ UEPG - Depto. de Física, Av. Gal. Carlos Cavalcanti, 4748 - 84030-900 - Ponta Grossa, PR - Brasil. \\ ${ }^{2}$ USP/Inst. de Física de São Carlos, C.P. 369 - 13560-970 - São Carlos, SP - Brasil. \\ ${ }^{3}$ UFRGS/Inst. de Geociências, Av. Bento Gonçalves, 9500 - 91501-970 - Porto Alegre, RS - Brasil. \\ ${ }^{4}$ USP/Inst. de Física, C.P. 66318 - 05315-970 - São Paulo, SP - Brasil. \\ 'Embrapa Instrumentação Agropecuária, C.P. 741 - 13560-970 - São Carlos, SP - Brasil. \\ *Corresponding author < brinatti@uepg.br>
}

\begin{abstract}
The mineralogical characterization through mineral quantification of Brazilian soils by X-ray diffraction data using the Rietveld Method is not common. A mineralogical quantification of an Acric Ferralsol from the Ponta Grossa region, state of Paraná, Brazil, was carried out using this Method with X-Ray Diffraction data to verify if this method was suitable for mineral quantification of a highly-weathered soil. The A, AB and $\mathrm{B}_{3}$ horizons were fractioned to separate the different particle sizes: clay, silt, fine sand (by Stokes Law) and coarse sand fractions (by sieving), with the procedure free of chemical treatments. X-ray Fluorescence, Inductively Coupled Plasma Atomic Emission Spectrometry, Infrared Spectroscopy and Mössbauer Spectroscopy were used in order to assist the mineral identification and quantification. The Rietveld Method enabled the quantification of the present minerals. In a general way, the quantitative mineralogical characterization by the Rietveld Method revealed that quartz, gibbsite, rutile, hematite, goethite, kaolinite and halloysite were present in the clay and silt fractions of all horizons. The silt fractions of the deeper horizons were different from the more superficial ones due to the presence of large amounts of quartz. The fine and the coarse sand fractions are constituted mainly by quartz. Therefore, a mineralogical quantification of the finer fraction (clay and silt) by the Rietveld Method was successful.
\end{abstract}

Key words: Acric Ferralsol, clay fraction, silt fraction, mineralogical quantification, X-ray diffraction

\section{Caracterização mineralógica de um solo altamente intemperizado pelo Método de Rietveld}

\begin{abstract}
RESUMO: A caracterização mineralógica por meio da quantificação dos minerais presentes em solos brasileiros por difração de raios X usando o Método de Rietveld é, ainda, pouco comum. Neste trabalho foi realizada a quantificação mineralógica de um Latossolo Vermelho ácrico da região de Ponta Grossa, Paraná, Brasil, utilizando o Método de Rietveld com dados de Difração de Raios X e também verificado se o método foi adequado na quantificação mineral de um solo altamente intemperizado. Os horizontes $\mathrm{A}, \mathrm{AB}$ e $\mathrm{B}_{3}$ foram separados fisicamente nas frações: argila, silte, areia fina (por meio da Lei de Stokes) e areia grossa (por peneiramento) sem qualquer tratamento químico. As técnicas de Fluorescência de raios X, Espectroscopia de Emissão Atômica com Fonte de Plasma Induzido, Espectroscopia de Infravermelho e Espectroscopia Mössbauer foram utilizadas para auxiliar na identificação e quantificação dos minerais. O Método de Rietveld possibilitou a quantificação dos minerais presentes nas frações argila e silte de todos os horizontes: quartzo, gibbsita, rutílio, hematita, goethita, caulinita e haloisita. Na fração silte os horizontes mais profundos são diferentes do mais superficial devido à presença de grandes quantidades de quartzo. As frações areia fina e grossa são constituídas principalmente de quartzo. Portanto, o Método de Rietveld foi adequado para quantificação dos minerais, principalmente, das frações mais finas (argila e silte).

Palavras-chave: Latossolo Vermelho ácrico, fração argila, fração silte, quantificação mineralógica, difração de raios $\mathrm{X}$
\end{abstract}

\section{Introduction}

The commonest method for qualitative and quantitative mineral composition determination in soils is the $\mathrm{X}$-Ray Diffraction (XRD). However, in natural multimineral systems such as soils it is difficult to carry out the identification and the quantitative analysis by X-ray diffraction patterns mainly due to overlapping peaks (Bish, 1994).
The Rietveld Method (Rietveld, 1967; Rietveld, 1969) is a least-square whole-pattern-fitting structure refinement method, performed until the best fit is obtained between the complete observed powder diffraction pattern and entire calculated pattern. The whole calculated pattern is based on the simultaneously refined models for composition and crystal structure of each mineral phase (Young, 2002). The mineral quantification from multicomponent mixtures is determined through the

Sci. Agric. (Piracicaba, Braz.), v.67, n.4, p.454-464, July/August 2010 
scale factors refinement and provides accurate values of the relative abundance of the component phases (Hill and Howard, 1987; Bish and Howard, 1988).

Considering studies of mineralogical quantification using the Rietveld Method and XRD data for Brazilian soils, there are few studies reported. Viana et al. (2006) quantified main magnetic grains of iron oxides in the coarse fraction of a soil, Alves et al. (2007) evaluated the best sample preparation procedure of deferrified clays of a soil for quantification, Corrêa et al. (2008) studied the crystallographic characteristic of kaolinites characterizing also the clay fraction of a soil, and Alves et al. (2008) compared results of mineralogical quantification of kaolinite and gibbsite iron-free clay soil with obtained results by differential scanning calorimetry.

The use of XRD data and the Rietveld Method was evaluated for mineralogical quantification in the coarse sand, fine sand, silt and clay fractions of three horizons of a Ferralsol from Ponta Grossa, Brazil.

\section{Material and Methods}

Samples were collected from the $\mathrm{A}, \mathrm{AB}$ and $\mathrm{B}_{3}$ horizons of that corresponds to an Acric Ferralsol (FAO, 1994), corresponding to a Latossolo Vermelho Ácrico in accordance to the Brazilian Soil Classification System (Embrapa, 1999), from Ponta Grossa, Paraná, Brazil $\left(25^{\circ} 03^{\prime} \mathrm{S}\right.$; 50 $\left.0^{\circ} 03^{\prime} \mathrm{W}\right)$. Soil samples were obtained through physical fractionation process (Christensen, 1992; Tanner and Jackson, 1947; Embrapa, 1997) free of chemical treatment in four particle size ranges: coarse sand, fine sand, silt and clay fractions (Table 1).

X-Ray Fluorescence (XRF), Inductively Coupled Plasma Atomic Emission Spectrometry (ICP-AES), Infrared spectroscopy (IR) and Mössbauer Spectroscopy (MS) (Table 1) were also used in order to assist this identification and to corroborate the results obtained with the Rietveld and XRD methods. The XRF (Jones et al., 2000; Alves et al., 2007; Alves et al., 2008) as well as the ICP-AES (Fadigas et al., 2002; Abreu Jr., et al.,
2003; Giarola et al., 2009) are useful techniques in the determination of the elementary soil chemical composition. The former, however, requires larger samples in relation to the latter. The IR technique is frequently used for studies of the organic matter in Brazilian soils (Pérez et al., 2004; Silva et al., 2008), but it may disclose mineral presence in the soil through vibrations of inorganic ions in the region of medium infrared (Gonçalves et al., 2008). Mössbauer Spectroscopy is an alternative technique, sensitive only to $\mathrm{Fe}$-containing compounds (Viana et al., 2006). It is especially suited for minerals in which the $\mathrm{Fe}$ phases are present in minor quantities or when they are too fine-grained and have been extensively used in soils, sediments and gossans (Oliveira et al., 1996; Berquó et al., 2004; Curi et al., 2008; Otero et al., 2009).

The coarse sand and clay fractions (Table 1) were analyzed by XRF on a Philips PW2400 XRF spectrometer. However, this technique requires samples of $2 \mathrm{~g}$, and this amount was only available for two of the fractions cited above. The pellets were prepared with the dry samples according to the method described by Mori et al. (1999).

The fine sand and silt fractions (Table 1) were analyzed by ICP-AES. Samples were prepared according to a protocol proposed by Janasi et al. (1995). Analyses were performed on an ARL - 3410 model with sequential spectrometer using solutions obtained by alkaline fusion of sample powder with a mixture of lithium tetra metaborate.

In order to obtain the spectra by IR of the twelve samples (Table 1), compressed pellets were prepared with $2 \mathrm{mg}$ of dry sample and $100 \mathrm{mg}$ of $\mathrm{KBr}$ and kept free of humidity under vacuum (Gadsden, 1975; Russel, 1987). A Nicolet Magna 560 IR spectrometer was used in the absorbance mode with $4 \mathrm{~cm}^{-1}$ resolution. For the region of wave number between $4000 \mathrm{~cm}^{-1}$ and $400 \mathrm{~cm}^{-1}$ a CsI detector and a CsI beam-splitter were used and 64 scans performed on each sample, so that an average sepectrum was recorded. The OMNIC NICOLET FTIR software was used to obtain the spectra.

Table 1 - Samples, horizons, fractions and techniques.

\begin{tabular}{lccc}
\hline Samples & Horizons $($ depth/m) & Fractions & Techniques \\
\hline $\mathrm{A}_{\mathrm{cl}}$ & $\mathrm{A}(0.00-0.13)$ & clay $(\mathrm{cl})$ & XRF, IR, MS, \\
$\mathrm{AB}_{\mathrm{cl}}$ & $\mathrm{AB}(0.13-0.29)$ & $(\leq 2 \mu \mathrm{m})$ & preliminary tests XRD and \\
$\mathrm{B}_{3 \mathrm{cl}}$ & $\mathrm{B}_{3}(0.89-1.16)$ & & Rietveld Method \\
\hline $\mathrm{A}_{\mathrm{sl}}$ & $\mathrm{A}(0.00-0.13)$ & silt $(\mathrm{sl})$ & ICP-AES, IR, \\
$\mathrm{AB}_{\mathrm{sl}}$ & $\mathrm{AB}(0.13-0.29)$ & $(2-20 \mu \mathrm{m})$ & XRD and \\
$\mathrm{B}_{3 \mathrm{sl}}$ & $\mathrm{B}_{3}(0.89-1.16)$ & & Rietveld Method \\
\hline $\mathrm{A}_{\mathrm{fs}}$ & $\mathrm{A}(0.00-0.13)$ & $(20-53 \mu \mathrm{m})$ & ICP-AES, IR, \\
$\mathrm{AB}_{\mathrm{fs}}$ & $\mathrm{AB}(0.13-0.29)$ & & XRD and \\
$\mathrm{B}_{3 \mathrm{fs}}$ & $\mathrm{B}_{3}(0.89-1.16)$ & coarse sand $(\mathrm{cs})$ & Rietveld Method \\
\hline $\mathrm{A}_{\mathrm{cs}}$ & $\mathrm{A}(0.00-0.13)$ & $(53 \mu \mathrm{m}-1000 \mu \mathrm{m})$ & XRF, IR, \\
$\mathrm{AB}_{\mathrm{cs}}$ & $\mathrm{AB}(0.13-0.29)$ & & XRD and \\
$\mathrm{B}_{3 \mathrm{cs}}$ & $\mathrm{B}_{3}(0.89-1.16)$ & & Rietveld Method \\
\hline
\end{tabular}

Sci. Agric. (Piracicaba, Braz.), v.67, n.4, p.454-464, July/August 2010 
Only clay fractions (Table 1) were submitted to the MS because in these fractions the red color was more intense, which is an indication of the presence of $\mathrm{Fe}$, usually associated with very small particle sizes. In these cases, MS is a useful technique because there is interaction of $\mathrm{Fe}$ nuclei only with the absorption of $\gamma$-radiation, which is immediately sensitive to the environment. Moreover, only samples with no more than about $1 \%$ in weight, of iron can be studied. MS data were measured with a conventional constant-acceleration spectrometer with ${ }^{57} \mathrm{Co}$ in a $\mathrm{Rh}$ source. The absorbers were prepared by compressing finely ground samples between two acrylic plates with a sample thickness of $10 \mathrm{mg} \mathrm{cm}^{-2}$ Fe. A metallic iron foil was used for velocity calibration and as isomer shift reference. In order to check the magnetite presence all Mössbauer measurements were performed at room temperature and fitted using a leastsquare method with Lorentzian line shape.

The XRD analyses were carried out using an automatic horizontal diffractometer, rotating anode RIGAKU ROTAFLEX generator, Ru-200B model, with $\mathrm{CuKa}$ radiation operating at $50 \mathrm{kV}$ and $100 \mathrm{~mA}$. The preliminary XRD was carried out in the continuous scanning mode with speed of $2^{\circ}$ per min., within the range of $5^{\circ} \leq 2 \theta \leq 40^{\circ}$. To use the Rietveld Method, XRD data were collected in the step-scan mode within the range of $5^{\circ} \leq 2 \theta \leq 70^{\circ}$, step size of $0.02^{\circ}$ in $2 \theta$ and a counting time of $2 \mathrm{~s}$ per step. All data were collected with a divergence slit: $1.00^{\circ}$, reception slit: $0.30^{\circ}$, scattering slit: $1.00^{\circ}$. All samples (Table 1) were powdered and sieved (53 $\mu \mathrm{m}$ aperture), placed and lightly pressed on the standard sample holder of front-loading powder.

The identification of minerals in clay fractions with preliminary tests (Table 1) had the following procedure: i) drying and heating in a stove at $100^{\circ} \mathrm{C}$; ii) treating with ethylene-glycol; and iii) XRD data with in situ thermal treatments were collected at constant temperatures $\left(25^{\circ} \mathrm{C}, 200^{\circ} \mathrm{C}, 350^{\circ} \mathrm{C}, 475^{\circ} \mathrm{C}\right.$, and $\left.575^{\circ} \mathrm{C}\right)$.

The Rietveld Method was applied using the program DBWS 9807a (Young, 1995; Young et al., 2000). The strategy adopted for the Rietveld Method refinement was that advised by Young (2002), slightly modified: i) All scale factors were adjusted at the same time; ii) For each phase, the scale factor, overall temperature factor, lattice parameters, U, V, W parameters of the full-widths at half maximum function (Caglioti et al., 1958), NA and NB parameters, both referring to the $\eta$ parameter of the profile pseudo-Voigt function, were adjusted separately one by one and then simultaneously. Later all the preceding parameters were treated simultaneously. This part of the procedure was successful for the phases that existed in larger amounts but, for phases in less amounts, it was not always possible to carry it through completely; iii) The six terms of the polynomial function used to model the background were refined one by one and finally together; iv) All the scale factors, the six terms of the background function, the sample displacement, and the zero- $2 \theta$ were adjusted simultaneously; v)
To finish only the scale factors of each phase they were adjusted once more and simultaneously.

The refinement progress of each sample was evaluated by numerical criteria, or disagreement indexes, defined by the method using the program DBWS 9807a, namely R-Bragg factor $\left(R_{B}\right)$, R-structure factor $\left(R_{F}\right)$, Rpattern $\left(R_{p}\right)$, R-weighted pattern $\left(R_{w p}\right)$, R-expected $\left(R_{\text {exp }}\right)$, goodness-of-fit $(S)$, Durbin-Watson statistic $\left(d_{d w}\right)$ and estimated standard deviation (Young, 1995; Young et al., 2000).

The crystalline structure data of each phase were taken from literature. For details see: Will et al. (1988) for quartz; Saalfeld and Wedde (1974) for gibbsite; Howard et al. (1991) and Sabine and Howard (1982) for rutile; Tsirel'son et al. (1988) for hematite, Hazemann et al. (1991) for goethite; Bish and von Dreele (1989) for kaolinite; and Mehmel (1935) for halloysite.

More abundant oxides determined by XRF (clay fractions) or ICP-AES (silt fractions) were compared with oxide amounts calculated by the Rietveld Method. The calculations were carried out taking into consideration the ideal stoichiometry of minerals, thus quartz $\left(\mathrm{SiO}_{2}\right)$ : $100.00 \%\left(\mathrm{SiO}_{2}\right)$; gibbsite $\left[\mathrm{Al}(\mathrm{OH})_{3}\right]: 65.36 \%\left(\mathrm{Al}_{2} \mathrm{O}_{3}\right)$; rutile $\left(\mathrm{TiO}_{2}\right): 100.00 \%\left(\mathrm{TiO}_{2}\right)$; hematite $\left(\mathrm{Fe}_{2} \mathrm{O}_{3}\right): 100.00 \%$ $\left(\mathrm{Fe}_{2} \mathrm{O}_{3}\right)$; goethite $[\mathrm{FeO}(\mathrm{OH})]: 89.86 \%\left(\mathrm{Fe}_{2} \mathrm{O}_{3}\right)$; kaolinite and halloysite: $\left[\mathrm{Al}_{2} \mathrm{Si}_{2} \mathrm{O}_{5}(\mathrm{OH})_{4}\right]: 39.50 \%\left(\mathrm{Al}_{2} \mathrm{O}_{3}\right)$ and $46.55 \%\left(\mathrm{SiO}_{2}\right)$.

The percentage of goethite and hematite determined by MS were also compared with the Rietveld Method. Considering the hematite and goethite as total contents of Fe oxides determined by the Rietveld Method, the percentage for hematite and goethite was calculated.

\section{Results and Discussion}

All peaks in the XRD patterns of preliminary tests for clay fractions (Table 1) presented diffraction peaks associated with the kaolinite-serpentine group, at $12.30^{\circ}$ $2 \theta$ approximately, and one may be due either to $(1.0 \mathrm{~nm})$ -halloysite or to $(0.7 \mathrm{~nm})$-halloysite. However, in each analysis performed at room temperature, with the samples previously treated with ethylene-glycol, the peak at $12.30^{\circ} 2 \theta$ did not change its position, confirming the presence of the $(0.7 \mathrm{~nm})$-halloysite (Brown, 1980; Brown and Brindley, 1980; Moore and Reynolds, 1989). The XRD patterns at $25^{\circ} \mathrm{C}$ and $200^{\circ} \mathrm{C}$ had overlapping diffraction peaks related to quartz, gibbsite, rutile, hematite, goethite, kaolinite and halloysite. The gibbsite diffraction peaks of the samples heated at $350^{\circ} \mathrm{C}$ vanished. With the heating at $475^{\circ} \mathrm{C}$ the kaolinite-serpentine group characteristic peaks practically disappeared due to the transformation of $(0.7 \mathrm{~nm})$-halloysite into amorphous material. Only at $575^{\circ} \mathrm{C}$ these peaks definitely vanished indicating the kaolinite amorphisation. At this temperature, hematite characteristic peaks were clearly identified because the overlapping kaolinite-serpentine group peaks, which usually mask hematite peaks, disappeared. Also at this temperature the goet- 
hite began to transform into hematite, strengthening its peaks. But, it was possible to notice one quartz peak.

Because XRD, Rietveld Method, IR and MS results obtained in the analyses of these three samples of the clay fraction were similar, only the $\mathrm{A}_{\mathrm{cl}}$ results are shown. The results of the XRD pattern fitted by the Rietveld Method are presented in Figure 1. The mineral composition obtained and the Rietveld Method disagreement indexes for the refinement are presented in Table 2. XRF data show the predominance of $\mathrm{Si}, \mathrm{Al}, \mathrm{Fe}, \mathrm{Ti}$ and $\mathrm{Na}$ (Table 3). The results for clay fractions are similar, but there is an increase in the amount of the first four ox-

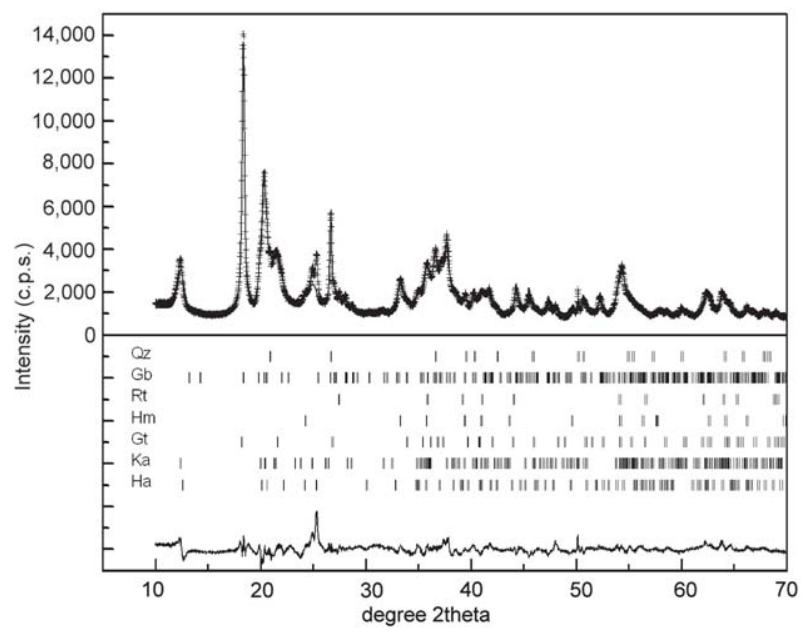

Figure 1 - XRD pattern of the clay fraction $\left(\mathrm{A}_{\mathrm{c}}\right)$. Counts per second (c.p.s.). Crosses indicate the observed profile, solid line indicates the calculated profile, and the residual curve is shown in solid line below the Bragg peak positions in vertical lines. Qz-quartz; Gbgibbsite; Rt-rutile; Hm-hematite; Gt-goethite; Kakaolinite; Ha-halloysite. ides from the most superficial horizon $\left(\mathrm{A}_{\mathrm{c}}\right)$ to the deepest $\left(\mathrm{B}_{3 \mathrm{c}}\right) . \mathrm{Na}$ is present in these samples because in the physical soil fractionation process $\mathrm{NaOH}$ was added to soil suspensions to facilitate the disaggregation of particles. The IR spectrum (Figure 2) permitted the identification of the presence of gibbsite, quartz and the kaolinite-serpentine group minerals: kaolinite and halloysite. The MS analyses permitted to verify the presence of hematite and goethite (Figure 3 and Table 4). The hematite sextet and goethite doublet adjusted well to the profile data, and confirmed the presence of these minerals.

Only the Rietveld Method fitting results of the XRD pattern for $\mathrm{A}_{\mathrm{sl}}$ are presented in Figure 4 because the other results for silt fraction were similar. Mineral composition and the disagreement indexes are presented in Table

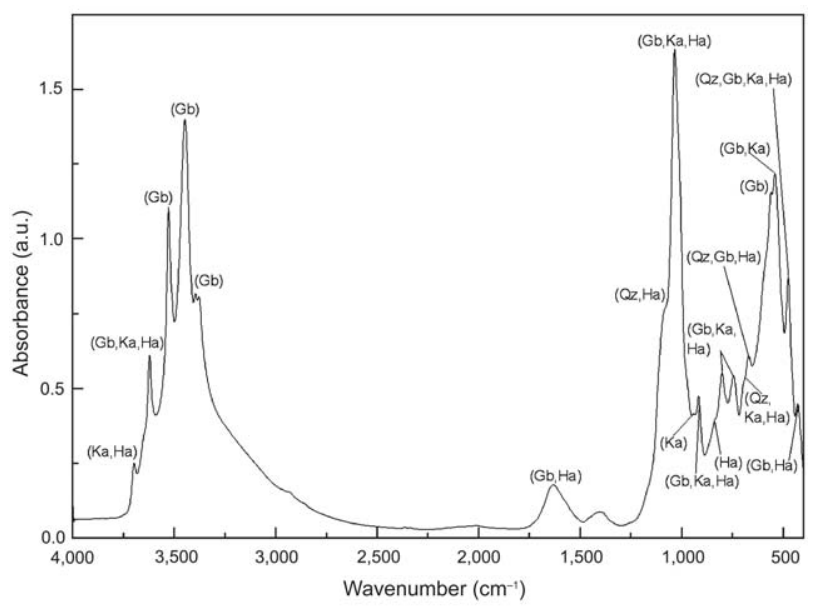

Figure 2 - IR data of the clay fraction $\left(\mathrm{A}_{\mathrm{c}}\right)$ in the range of 4000 $\mathrm{cm}^{-1}$ to $400 \mathrm{~cm}^{-1}$. Arbitrary units (a.u.). Qz-quartz; Gb-gibbsite; Ka-kaolinite; Ha-halloysite.

Table 2 - Rietveld Method results of the mineral composition and disagreement indexes of the clay fractions.

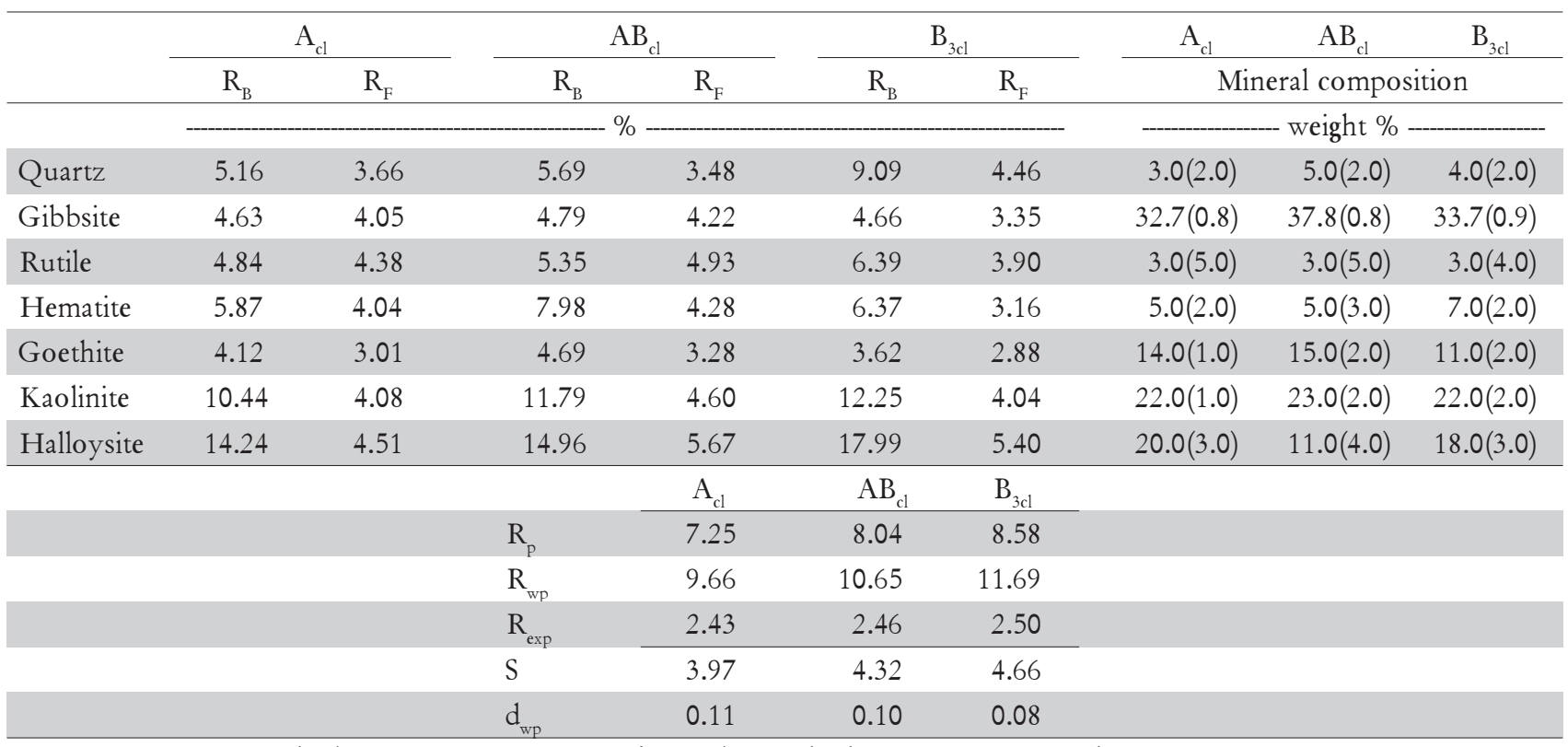

$R_{B}, R_{F}, R_{p}, R_{w p}, R_{\text {exp }}, S, d_{d w}(Y o u n g, 1995$; Young et al., 2000). Standard errors are in parentheses. 
Table 3 - XRF data for the clay and coarse sand fractions.

\begin{tabular}{|c|c|c|c|c|c|c|c|}
\hline Oxides & $\mathrm{A}_{\mathrm{cl}}$ & $\mathrm{AB}_{\mathrm{cl}}$ & $\mathrm{B}_{3 \mathrm{cl}}$ & $\mathrm{A}_{\mathrm{cs}}$ & $\mathrm{AB}_{\mathrm{cs}}$ & $\mathrm{B}_{3 c s}$ & DL \\
\hline & & - & - & weight \% & - & 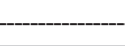 & - \\
\hline $\mathrm{SiO}_{2}$ & 13.86 & 13.98 & 14.17 & 96.76 & 92.60 & 97.20 & 0.03 \\
\hline $\mathrm{Al}_{2} \mathrm{O}_{3}$ & 38.46 & 39.71 & 42.46 & 0.90 & 3.37 & 0.33 & 0.02 \\
\hline $\mathrm{Fe}_{2} \mathrm{O}_{3}$ & 13.96 & 14.50 & 15.18 & 0.59 & 1.15 & 0.29 & 0.01 \\
\hline $\mathrm{TiO}_{2}$ & 1.927 & 1.982 & 2.163 & 0.193 & 0.427 & 0.198 & 0.003 \\
\hline $\mathrm{MgO}$ & 0.38 & 0.29 & 0.24 & $<0.01$ & $<0.01$ & $<0.01$ & 0.01 \\
\hline $\mathrm{CaO}$ & 0.46 & 0.16 & 0.09 & 0.03 & 0.01 & 0.01 & 0.01 \\
\hline $\mathrm{K}_{2} \mathrm{O}$ & 0.191 & 0.160 & 0.154 & 0.008 & 0.021 & $<0.005$ & 0.01 \\
\hline $\mathrm{MnO}$ & 0.031 & 0.024 & 0.023 & 0.003 & 0.003 & 0.002 & 0.002 \\
\hline $\mathrm{P}_{2} \mathrm{O}_{5}$ & 0.314 & 0.149 & 0.085 & 0.021 & 0.017 & 0.012 & 0.003 \\
\hline $\mathrm{Na}_{2} \mathrm{O}$ & 2.55 & 2.31 & 2.20 & $<0.02$ & $<0.02$ & $<0.02$ & 0.02 \\
\hline $\mathrm{SO}_{3}$ & 0.088 & 0.062 & $<0.001$ & $<0.001$ & $<0.001$ & $<0.001$ & 0.001 \\
\hline LOI & 30.19 & 28.66 & 25.52 & 2.01 & 2.97 & 2.75 & 0.01 \\
\hline Total & 102.41 & 101.99 & 102.29 & 100.52 & 100.57 & 100.79 & - \\
\hline
\end{tabular}

LOI - Loss on ignition (LOI); DL - Detection Limit.

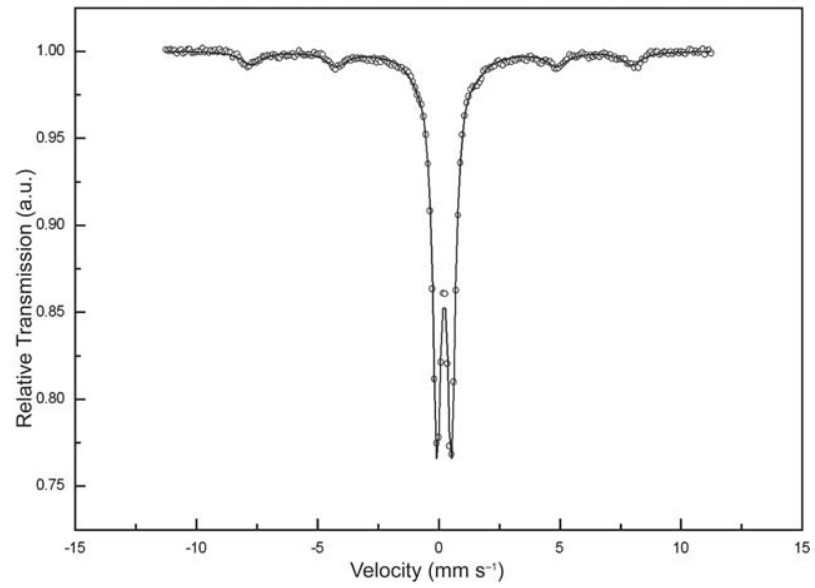

Figure 3 - MS data and fitted profile of the clay fraction $\left(\mathrm{A}_{\mathrm{c}}\right)$. Arbitrary units (a.u.). Circles indicate the data observed and solid line indicates the fitted profile.

5 for three samples. The ICP-AES analyses of the silt fractions (Table 6) show that the contents of Al decrease and Si increase when compared with the clay fractions (Table 3). The results for $\mathrm{A}_{\text {sl }}$ showed comparable amounts of $\mathrm{Al}$ and $\mathrm{Si}$ oxides, with a slight $\mathrm{Al}$ predominance, different from those for $\mathrm{AB}_{\mathrm{sl}}$ and $\mathrm{B}_{3 \mathrm{sl}}$ where the contents of $\mathrm{Si}$ are higher than $\mathrm{Al}$ (Table 6) and showed the existence of iron suggesting the presence of goethite and/or hematite. The IR spectrum for $\mathrm{A}_{\mathrm{sl}}$ permitted to identify gibbsite, clay minerals of the kaolinite-serpentine group: kaolinte and halloysite, and quartz in accordance with the bands at $805-796 \mathrm{~cm}^{-1}, 785-775 \mathrm{~cm}^{-1}$ and $697-692 \mathrm{~cm}^{-1}$ (Figure 5). However, the quartz presence is more evident for $\mathrm{AB}_{\mathrm{sl}}$ and $\mathrm{B}_{3 \mathrm{~s} \mathrm{l}}$ because the cited quartz bands are sharper, but these results were omitted here.

The results of the fitting of XRD patterns made by Rietveld Method for fine sand fractions are presented in Figure 6 only for $\mathrm{A}_{\mathrm{fs}}$, because the results are similar

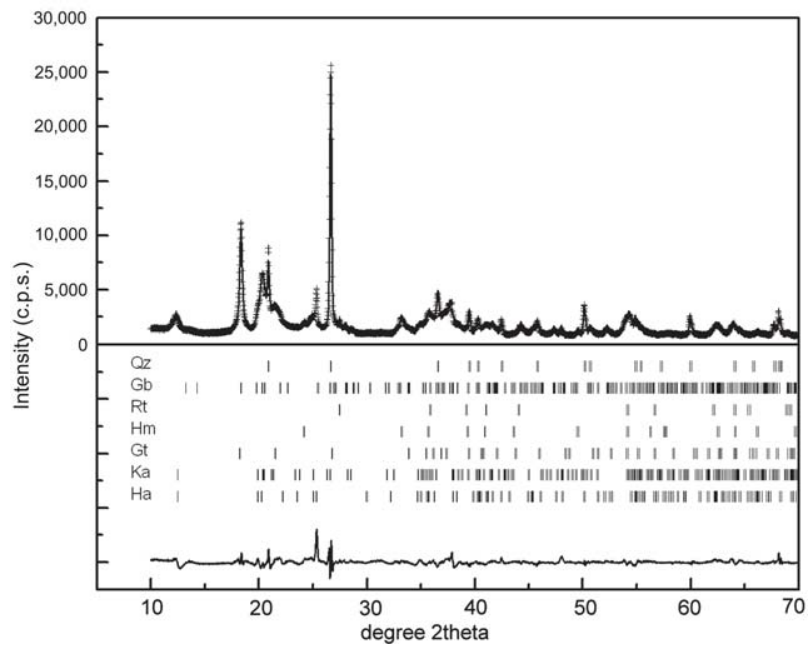

Figure $4-\mathrm{XRD}$ pattern of the silt fraction $\left(\mathrm{A}_{\mathrm{s}}\right)$. Counts per second (c.p.s.). Crosses indicate the observed profile, solid line indicates the calculated profile, and the residual curve is shown in solid line below the Bragg peak positions in vertical lines. Qz-quartz; Gbgibbsite; Rt-rutile; Hm-hematite; Gt-goethite; Kakaolinite; Ha-halloysite.

for the other samples $\left(\mathrm{AB}_{\mathrm{fs}}\right.$ and $\left.\mathrm{B}_{2 \mathrm{fs}}\right)$, and the differences are in the relative intensities. Results presented the refinement carried out by the Rietveld Method considering only quartz because attempts including other minerals as kaolinite-serpentine group, gibbsite, hematite, goethite and rutile were not successful, although it was possible to identify them, due to the intensity peaks of $\mathrm{XRD}$ at higher angles in the region of $67.5^{\circ}$ to $68.5^{\circ}$ (Figure 6), which were more intense than the quartz calculated pattern from crystal structure data. This may be related to particle size statistics effects, to insufficient grinding (Hill and Madsen, 2006) and the presence of not well crystallized minor mineral phases. For these rea- 
Table 4 - Adjusted results of the MS (hematite sextet and goethite doublet) of the clay fraction.

\begin{tabular}{lccc}
\hline Parameters & $\mathrm{A}_{\mathrm{cl}}$ & $\mathrm{AB}_{\mathrm{cl}}$ & $\mathrm{B}_{3 \mathrm{cl}}$ \\
\hline & & Goethite Dublet & \\
Quadrupole Splitting $\left(\mathrm{mm} \mathrm{s}^{-1}\right)$ & $0.59(0.01)$ & $0.58(0.01)$ & $0.57(0.01)$ \\
Isomer Shift (mm s$\left.{ }^{-1}\right)$ & $0.35(0.01)$ & $0.34(0.01)$ & $0.35(0.01)$ \\
Relative Área (\%) & $81(1)$ & $81(1)$ & $69(1)$ \\
& & Hematite Sextet & $481(2)$ \\
Magnetic Filed (kG) & $487(1)$ & $490(1)$ & $-0.16(0.05)$ \\
Quadrupole Splitting $\left(\mathrm{mm} \mathrm{s}^{-1}\right)$ & $-0.21(0.03)$ & $-0.22(0.03)$ & $0.41(0.02)$ \\
Isomer Shift (mm s-1) & $0.36(0.01)$ & $0.34(0.02)$ & $31(1)$ \\
Relative Area (\%) & $19(1)$ & $19(1)$ & \\
\hline
\end{tabular}

Standard errors are in parentheses.

Table 5 - Rietveld Method results of the mineral composition and disagreement indexes of the silt fractions.

\begin{tabular}{|c|c|c|c|c|c|c|c|c|c|}
\hline & \multicolumn{2}{|c|}{$\mathrm{A}_{\mathrm{cl}}$} & \multicolumn{2}{|c|}{$\mathrm{AB}_{\mathrm{cl}}$} & \multicolumn{2}{|c|}{$\mathrm{B}_{3 \mathrm{cl}}$} & $\mathrm{A}_{\mathrm{cl}}$ & $\mathrm{AB}_{\mathrm{cl}}$ & $\mathrm{B}_{3 \mathrm{cl}}$ \\
\hline & $\mathrm{R}_{\mathrm{B}}$ & $\mathrm{R}_{\mathrm{F}}$ & $\mathrm{R}_{\mathrm{B}}$ & $\mathrm{R}_{\mathrm{F}}$ & $\mathrm{R}_{\mathrm{B}}$ & $\mathrm{R}_{\mathrm{F}}$ & \multicolumn{3}{|c|}{ Mineral composition } \\
\hline & \multicolumn{9}{|c|}{ 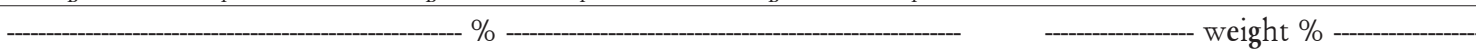 } \\
\hline Quartz & 4.72 & 3.56 & 5.63 & 5.07 & 7.82 & 7.43 & $18.6(0.8)$ & $66.1(0.5)$ & $65.0(0.5)$ \\
\hline Gibbsite & 3.67 & 2.70 & 13.28 & 9.93 & 12.11 & 8.96 & $23.0(1.0)$ & $8.0(3.0)$ & $10.0(3.0)$ \\
\hline Rutile & 5.24 & 2.96 & 7.79 & 5.94 & 11.30 & 8.74 & $2.0(5.0)$ & $2.0(4.0)$ & $2.0(4.0)$ \\
\hline Hematite & 5.99 & 2.86 & 10.74 & 4.94 & 14.21 & 7.08 & $4.0(3.0)$ & $3.0(4.0)$ & $5.0(3.0)$ \\
\hline Goethite & 4.17 & 2.45 & 7.83 & 3.90 & 15.36 & 9.37 & $14.0(2.0)$ & $11.0(4.0)$ & $4.0(7.0)$ \\
\hline Kaolinite & 8.32 & 3.05 & 18.79 & 8.46 & 18.93 & 10.25 & $17.0(2.0)$ & $10.0(3.0)$ & $14.0(3.0)$ \\
\hline \multirow[t]{7}{*}{ Halloysite } & 12.19 & 4.14 & & & & & $21.0(3.0)$ & & \\
\hline & & & & $\mathrm{A}_{\mathrm{cl}}$ & $\mathrm{AB}_{\mathrm{cl}}$ & $\mathrm{B}_{3 \mathrm{cl}}$ & & & \\
\hline & & & $\mathrm{R}_{\mathrm{p}}$ & 7.21 & 10.29 & 11.61 & & & \\
\hline & & & $\mathrm{R}_{\mathrm{wp}}$ & 10.01 & 14.03 & 16.45 & & & \\
\hline & & & $\mathrm{R}_{\text {exp }}$ & 2.42 & 2.30 & 2.36 & & & \\
\hline & & & $\mathrm{S}$ & 4.12 & 6.09 & 6.96 & & & \\
\hline & & & $\mathrm{d}_{\mathrm{wp}}$ & 0.14 & 0.17 & 0.25 & & & \\
\hline
\end{tabular}

$R_{B}, R_{F}, R_{p}, R_{w p}, R_{\text {exp }}, S, d_{d w}(Y o u n g, 1995$; Young et al., 2000). Standard errors are in parentheses.

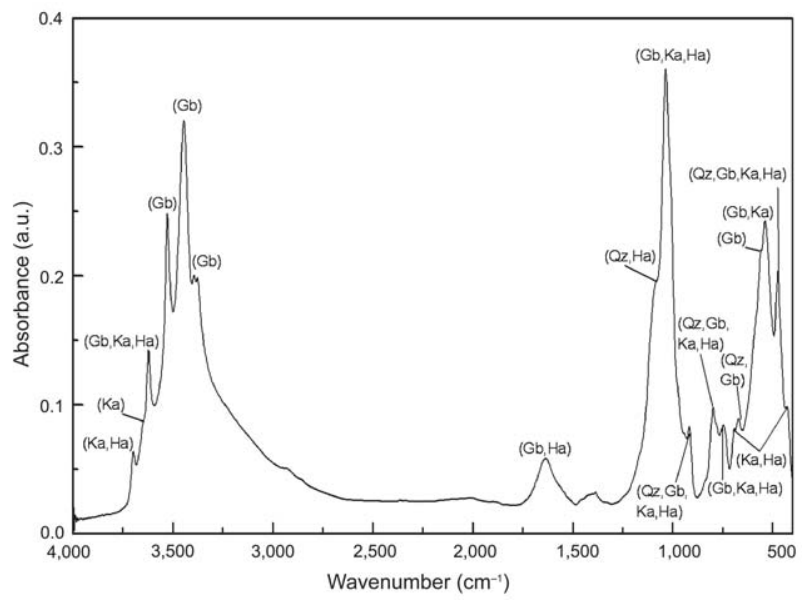

Figure 5 - IR data of the silt fraction $\left(\mathrm{A}_{\mathrm{s}}\right)$ in the range of 4000 $\mathrm{cm}^{-1}$ to $400 \mathrm{~cm}^{-1}$. Arbitrary units (a.u.). Qz-quartz; Gb-gibbsite; Ka-kaolinite; Ha-halloysite. sons it was decided to include only quartz in the refinement. The mineral composition and the disagreement indexes obtained are shown in Table 7.

As all samples were powdered by hand and sieved (aperture of sieve: $53 \mu \mathrm{m}$ ) it may be considered that it would have been better to attain a smaller particle size with a median diameter $<5 \mu \mathrm{m}$. This might also have made the adjustment and quantification of the minor phases more difficult, proposed for these samples and also for the coarse sand fraction (Hill and Madsen, 2006).

The results of the ICP-AES analyses for the fine sand fractions (Table 6) confirm the $\mathrm{Si}$ predominance and $\mathrm{Al}$ decrease when compared with the clay and silt fractions results. There is less amount of $\mathrm{Si}$ in the $\mathrm{A}_{\mathrm{fs}}$ sample than in $\mathrm{AB}_{\mathrm{fs}}$ and $\mathrm{B}_{3 \mathrm{fs}}$. The presence of $\mathrm{Al}, \mathrm{Ti}$ and $\mathrm{Fe}$ oxides could indicate the presence of gibbsite, rutile, hematite and goethite (Table 6). As the IR analyses for $\mathrm{AB}_{\mathrm{fs}}$ and $B_{3 f s}$ presented similar results deferring only in intensity

Sci. Agric. (Piracicaba, Braz.), v.67, n.4, p.454-464, July/August 2010 
Table 6 - ICP-AES data of silt and fine sand fractions.

\begin{tabular}{|c|c|c|c|c|c|c|c|}
\hline Oxides & $\mathrm{A}_{\mathrm{cl}}$ & $\mathrm{AB}_{\mathrm{cl}}$ & $\mathrm{B}_{3 \mathrm{cl}}$ & $\mathrm{A}_{\mathrm{cs}}$ & $\mathrm{AB}_{\mathrm{cs}}$ & $\mathrm{B}_{3 \mathrm{cs}}$ & $\mathrm{DL}$ \\
\hline & (-_. & 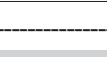 & 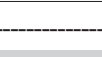 & weight & . & 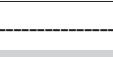 & . \\
\hline $\mathrm{SiO}_{2}$ & 27.67 & 55.98 & 56.44 & 81.35 & 91.56 & 91.43 & 0.02 \\
\hline $\mathrm{Al}_{2} \mathrm{O}_{3}$ & 29.64 & 13.09 & 13.77 & 6.01 & 1.34 & 1.51 & 0.01 \\
\hline $\mathrm{Fe}_{2} \mathrm{O}_{3}$ & 11.9 & 7.59 & 8.53 & 3.64 & 1.97 & 1.86 & 0.006 \\
\hline $\mathrm{TiO}_{2}$ & 3.35 & 6.18 & 7.48 & 2.99 & 3.39 & 3.38 & 0.006 \\
\hline $\mathrm{MgO}$ & 0.27 & 0.24 & 0.25 & 0.13 & 0.09 & 0.08 & 0.01 \\
\hline $\mathrm{CaO}$ & 0.34 & 0.22 & 0.08 & 0.21 & 0.04 & 0.01 & 0.006 \\
\hline $\mathrm{K}_{2} \mathrm{O}$ & 0.12 & 0.24 & 0.31 & 0.03 & 0.02 & $<0.01$ & 0.03 \\
\hline $\mathrm{MnO}$ & 0.04 & 0.06 & 0.06 & 0.02 & 0.02 & 0.02 & 0.006 \\
\hline $\mathrm{P}_{2} \mathrm{O}_{5}$ & 0.20 & 0.11 & 0.10 & 0.16 & 0.02 & 0.01 & 0.01 \\
\hline $\mathrm{Na}_{2} \mathrm{O}$ & $<0.01$ & $<0.01$ & $<0.01$ & $<0.01$ & $<0.01$ & $<0.01$ & 0.01 \\
\hline LOF & 25.07 & 15.44 & 11.64 & 5.28 & 1.91 & 1.88 & 0.01 \\
\hline Total & 98.60 & 99.16 & 98.67 & 99.83 & 100.37 & 100.19 & \\
\hline $\mathrm{H}_{2} \mathrm{O}-$ & 3.28 & 1.43 & 0.98 & 0.41 & 0.11 & 0.03 & \\
\hline
\end{tabular}

LOF-Loss on fusion. $\mathrm{H}_{2} \mathrm{O}$ - Hygroscopic or absorbed water; DL - Detection Limit.

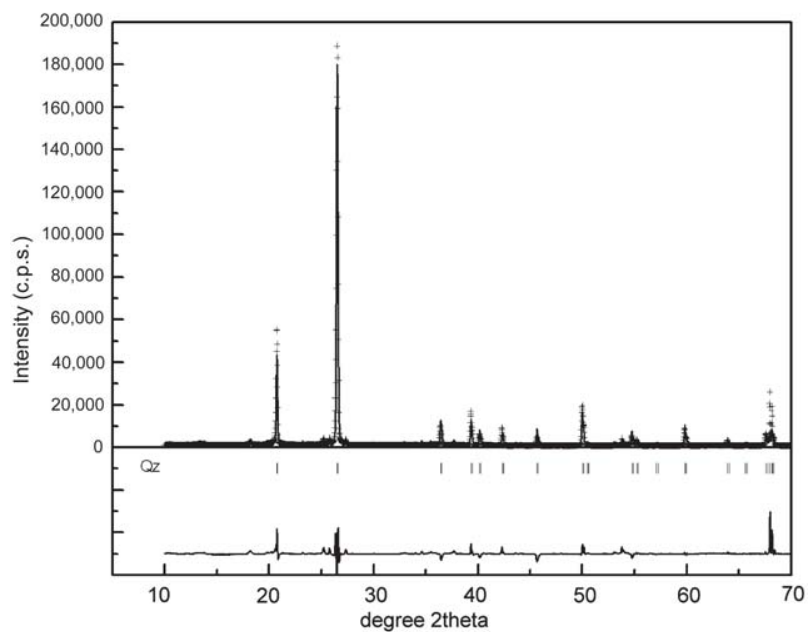

Figure $6-\mathrm{XRD}$ pattern of the fine sand fraction $\left(\mathrm{A}_{\mathrm{fs}}\right)$. Counts per second (c.p.s.). Crosses indicate the observed profile, solid line indicates the calculated profile, and the residual curve is shown in solid line below the Bragg peak positions in vertical lines. Qz-quartz.

for $\mathrm{A}_{\mathrm{fs}}$, results are shown only for $\mathrm{A}_{\mathrm{fs}}$ in Figure 7. In the three cases, the IR bands at $805-796 \mathrm{~cm}^{-1}, 796-775 \mathrm{~cm}^{-1}$ and $697 \mathrm{~cm}^{-1}$ show the quartz presence, bands between 3685 $\mathrm{cm}^{-1}$ and $3360 \mathrm{~cm}^{-1}$ indicate gibbsite, and those between $3710 \mathrm{~cm}^{-1}$ and $3250 \mathrm{~cm}^{-1}$ the kaolinite serpentine group minerals: kaolinite and halloysite. However, comparing the results it can be noticed that the $\mathrm{A}_{\mathrm{fs}}$ has the gibbsite and kaolinite-serprentine group bands regions more evident in agreement with the $\mathrm{Al}$ oxides amount which result in different intensities.

For the coarse sand fractions that presented similar results for XRD and Rietveld Method, an intensity difference, only the $A_{c s}$ fraction results are presented in Figure 8 and Table 7. In the same way as for the fine sand fraction, the refinement was carried out by the Rietveld

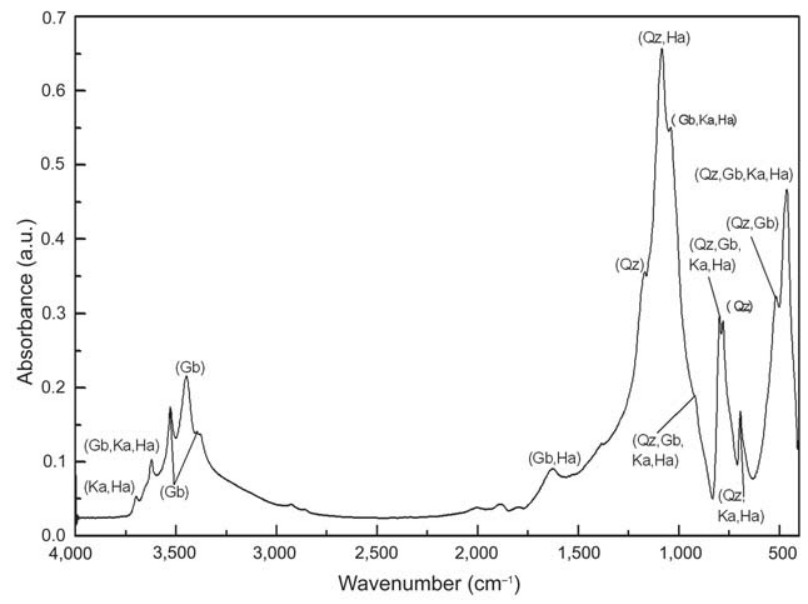

Figure 7 - IR data of the fine sand fraction $\left(\mathrm{A}_{\mathrm{fs}}\right)$ in the 4000 $\mathrm{cm}^{-1}$ to $400 \mathrm{~cm}^{-1}$ range. Arbitrary units (a.u.). Qzquartz; Gb-gibbsite; Ka-kaolinite; Ha-halloysite.

Method considering only quartz. The XRF results permitted to verify the Si predominance and Al, Fe and Ti oxides in quite smaller amounts (Table 3). However, $\mathrm{A}_{\mathrm{cs}}$ presented a slightly smaller amount of $\mathrm{Si}$ oxide in relation to $\mathrm{AB}_{\mathrm{cs}}$ and $\mathrm{B}_{3 \mathrm{cs}}$. The IR spectra have shown bands between $1200 \mathrm{~cm}^{-1}$ and $450 \mathrm{~cm}^{-1}$ that confirm the existence of quartz in these fractions. $A s \mathrm{AB}_{c s}$ and $\mathrm{B}_{3 \mathrm{cs}}$ are similar to $A_{c s}$, they were omitted. IR spectra is shown for $A_{c s}$ in Figure 9.

A comparison of more abundant oxides determined by XRF (clay fraction) or ICP-AES (silt fraction) and oxides amounts calculated by the Rietveld Method is shown in Table 8. In general, contents of Si oxides were overestimated, contents of $\mathrm{Al}$ oxides were comparable, exceptions were $B_{3 c l}$ and $A_{s}$, as well as contents of $\mathrm{Fe}$ oxides, exceptions were $A_{c l}, A_{s 1}$ and $A_{s}$, and contents of $\mathrm{Ti}$ oxides were overestimated for the clay fraction and underestimated for the silt fraction. 
Table 7 - Rietveld Method results of the mineral composition and disagreement indexes of the fine and coarse sand fractions.

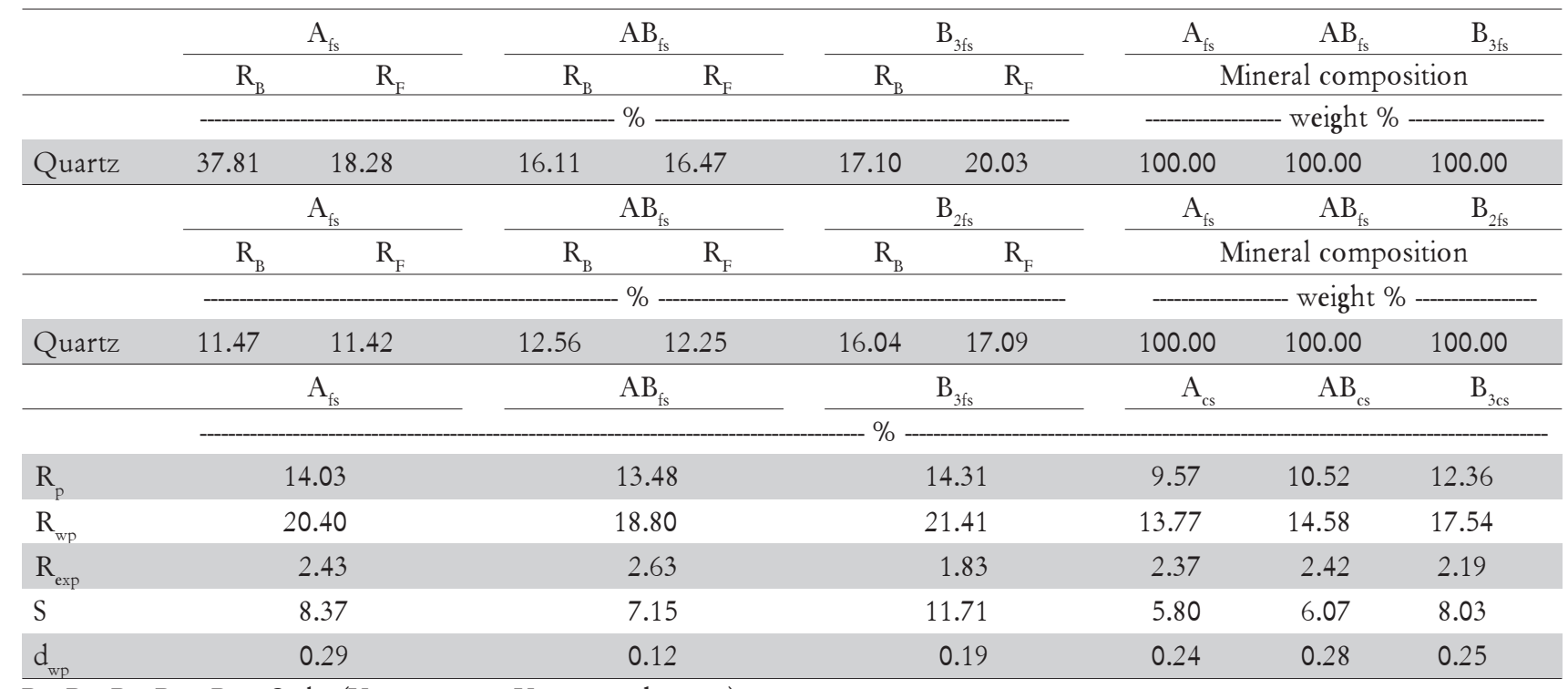

$\mathrm{R}_{\mathrm{B}}, \mathrm{R}_{\mathrm{F}}, \mathrm{R}_{\mathrm{p}}, \mathrm{R}_{\mathrm{wp}}, \mathrm{R}_{\text {exp }}, \mathrm{S}, \mathrm{d}_{\mathrm{dw}}$ (Young, 1995; Young et al., 2000).

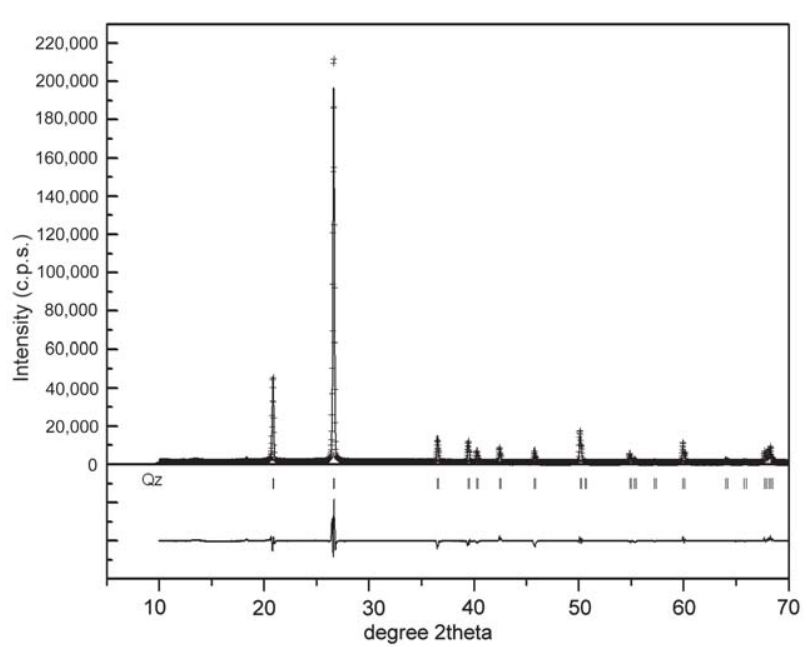

Figure 8 - XRD pattern of the coarse sand fraction $\left(\mathrm{A}_{\mathrm{cs}}\right)$. Counts per second (c.p.s.). Crosses indicate the observed profile, solid line indicates the calculated profile, and the residual curve is shown in solid line below the Bragg peak positions in vertical lines. Qz-quartz.

The percentage of goethite and hematite determined by MS and by the Rietveld Method (Table 9) show that contents of hematite were overestimated by the Rietveld Method, however there is agreement in the higher contents of goethite. Although the Rietveld Method gives a quantitative description of the fractions composition, a search for a good indication of the different phases present in each sample was performed through previous use of several spectroscopic techniques, also reported in studies of Brazilian soils by Viana et al. (2006); Alves et al. (2007); Corrêa et al. (2008) and Alves et al. (2008). However, these studies were carried out with a different software than the one used here.

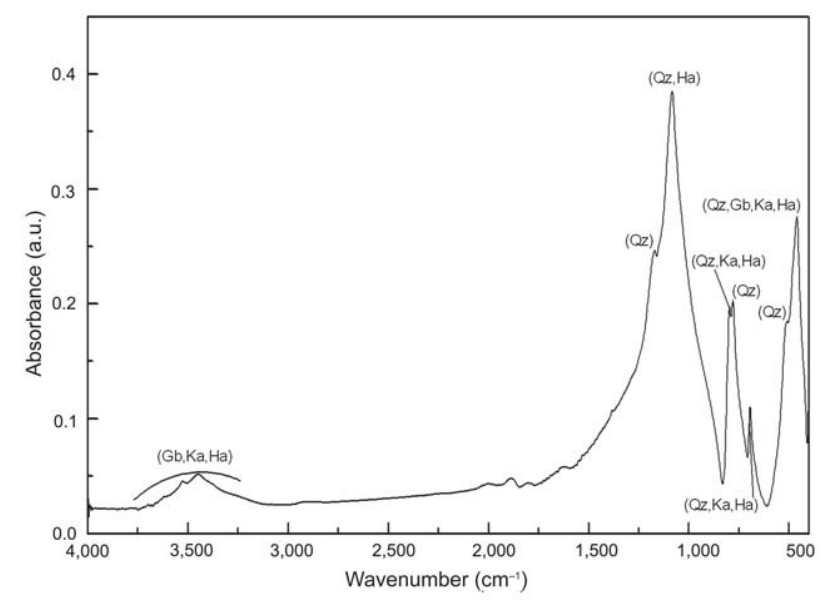

Figure 9 - IR data of the coarse sand fraction (A ) in the 4000 $\mathrm{cm}^{-1}$ to $400 \mathrm{~cm}^{-1}$ range. Arbitrary units (a.u.). Qzquartz; Gb-gibbsite; Ka-kaolinite; Ha-halloysite.

Rietveld Method results for the clay fractions (Figure 1 and Table 2) showed that quartz result agrees with the XRF (Table 3) and the IR results (Figure 2). Amounts of Si oxides calculated by Rietveld Method, however, were overestimated (Table 8). Gibbsite is in agreement with XRF data that indicated great amount of $\mathrm{Al}$ (Table $3)$. These results are comparable to the amount of $\mathrm{Al}$ oxides calculated by Rietveld Method (Table 8), and the IR data also showed characteristic bands of gibbsite (Figure 2) that were confirmed by XRD preliminary tests, of which characteristic peaks began to disappear at $350^{\circ}$ C. The presence of $\mathrm{Ti}$ determined by XRF indicates rutile presence (Table 3 ), but the amounts of $\mathrm{Ti}$ oxides calculated by Rietvled Method were overestimated (Table 8). XRF analyses indicated the presence of Fe and permitted to suppose the existence of hematite and go- 
Table 8 - Comparison of amounts of more abundant oxides by XRF or ICP-AES and Rietveld Method.

\begin{tabular}{|c|c|c|c|c|c|c|}
\hline \multirow{2}{*}{ Oxides } & \multicolumn{2}{|r|}{$\mathrm{A}_{\mathrm{cl}}$} & \multicolumn{2}{|r|}{$\mathrm{AB}_{\mathrm{cl}}$} & \multicolumn{2}{|r|}{$\mathrm{B}_{3 \mathrm{cl}}$} \\
\hline & $\mathrm{XRF}$ & Rietveld Method & $\mathrm{XRF}$ & Rietveld Method & XRF & Rietveld Method \\
\hline & \multicolumn{6}{|c|}{ - } \\
\hline $\mathrm{SiO}_{2}$ & 13.86 & 22.55 & 13.98 & 20.83 & 14.17 & 22.62 \\
\hline $\mathrm{Al}_{2} \mathrm{O}_{3}$ & 38.46 & 37.96 & 39.71 & 38.14 & 42.46 & 37.83 \\
\hline $\mathrm{Fe}_{2} \mathrm{O}_{3}$ & 13.96 & 17.58 & 14.50 & 13.48 & 15.18 & 16.88 \\
\hline $\mathrm{TiO}_{2}$ & 1.927 & 3.00 & 1.982 & 3.00 & 2.163 & 3.00 \\
\hline \multirow{2}{*}{ Oxides } & \multicolumn{2}{|r|}{$\mathrm{A}_{\mathrm{cl}}$} & \multicolumn{2}{|r|}{$\mathrm{AB}_{\mathrm{cl}}$} & \multicolumn{2}{|r|}{$\mathrm{B}_{3 \mathrm{cl}}$} \\
\hline & ICP-AES & Rietveld Method & ICP-AES & Rietveld Method & ICP-AES & Rietveld Method \\
\hline & \multicolumn{6}{|c|}{ (3) weight \% } \\
\hline $\mathrm{SiO}_{2}$ & 27.67 & 36.29 & 55.98 & 70.76 & 56.44 & 71.52 \\
\hline $\mathrm{Al}_{2} \mathrm{O}_{3}$ & 29.64 & 30.04 & 13.09 & 9.18 & 13.77 & 12.07 \\
\hline $\mathrm{Fe}_{2} \mathrm{O}_{3}$ & 11.9 & 16.58 & 7.59 & 12.88 & 8.53 & 8.59 \\
\hline $\mathrm{TiO}_{2}$ & 3.35 & 2.00 & 6.18 & 2.00 & 7.48 & 2.00 \\
\hline
\end{tabular}

Table 9 - Comparison of the percentage of goethite and hematite by MS and Rietveld Method.

\begin{tabular}{|c|c|c|c|c|c|c|}
\hline \multirow{2}{*}{ Mineral } & \multicolumn{2}{|r|}{$\mathrm{A}_{\mathrm{cl}}$} & \multicolumn{2}{|r|}{$\mathrm{AB}_{\mathrm{cl}}$} & \multicolumn{2}{|r|}{$\mathrm{B}_{3 \mathrm{cl}}$} \\
\hline & MS & Rietved Method & MS & Rietveld Method & MS & RietveldMethod \\
\hline Hematite & 19 & 26 & 19 & 25 & 31 & 39 \\
\hline Goethite & 81 & 74 & 81 & 75 & 69 & 61 \\
\hline
\end{tabular}

ethite (Table 3), and the results of quantification of $\mathrm{Fe}$ oxides were comparable to the same oxides calculated by Rietveld Method (Table 8). These oxides were also confirmed by MS analyses that indicated the hematite sextet and goethite doublet (Figure 3 and Table 4). Moreover there is agreement in the higher contents of goethite than hematite (Table 9). In addition, the XRD preliminary tests after thermal treatments at $575^{\circ} \mathrm{C}$, the goethite began to transform into hematite strengthening its peaks. The kaolinite-serpentine group (kaolinite and halloysite) presence is in agreement with XRF data that indicated the presence of $\mathrm{Si}$ and $\mathrm{Al}$ (Table 3). However, in comparison to $\mathrm{Si}$ and $\mathrm{Al}$ oxides calculated by Rietveld Method, the former was overestimated and the latter presented comparable amount (Table 8). The IR spectra also showed the characteristic bands of kaolin minerals (Figure 2). Moreover the XRD preliminary tests after treatment with ethylene-glycol, discarded to $(1.0 \mathrm{~nm})$ halloysite possibility and sample heating at $475^{\circ} \mathrm{C}$ showed that the halloysite characteristic peaks disappeared and, at $575^{\circ} \mathrm{C}$, the kaolinite characteristic peaks vanished.

Rietveld Method results for the silt fractions (Figure 4 and Table 5) showed that quartz is in agreement with the ICP-AES analyses (Table 6) for $\mathrm{A}_{\mathrm{sl}}$, and quartz is predominant in $\mathrm{AB}_{\mathrm{s}}$ and $\mathrm{B}_{3 \mathrm{~s}}$, however, Si oxides calculated by Rietveld Method were overestimated (Table 8). The IR spectra also showed the characteristic bands of quartz in the three samples but with smaller amount in $\mathrm{A}_{\mathrm{sl}}$ (Figure 5). Gibbsite is predominant in $A_{s l}$ and appears in smaller amount for $\mathrm{AB}_{\mathrm{sl}}$ and $\mathrm{B}_{3 \mathrm{~s}}$, in agreement with $\mathrm{Al}$ oxide found by ICP-AES (Table 6), these results are comparable to Al oxides calculated by Rietveld Method (Table 8). In the IR spectra, the characteristic bands of this mineral were also observed for $A_{s l}$ (Figure 5) $A_{\text {sl }}$ and $\mathrm{B}_{3 \mathrm{~s}}$, but gibbsite bands intensities and regions are more evident for sample $A_{s t}$ than for $A_{s \mid}$ and $B_{3 s \mid}$ because in the former the amounts of $\mathrm{Si}$ oxide are comparable to those for $\mathrm{Al}$ oxide. The ICP-AES analyses indicate Ti (Table 6) in agreement with rutile presence, however, Ti oxides calculated by Rietveld Method were underestimated. The Fe determined by ICP-AES (Table 6) is in agreement with the goethite and/or hematite presence, and these results were comparable to Fe oxides calculated by Rietveld Method (Table 8). The IR spectra also showed the characteristic bands of kaolinite and halloysite. In comparison with ICP-AES data that indicated the $\mathrm{Si}$ and $\mathrm{Al}$ presence (Table 6), the amounts of Si oxides calculated by Rietveld Method were overestimated and the amounts of $\mathrm{Al}$ oxides were comparable (Table 8). But the kaolinite-serpentine group bands are more intense for $A_{s \mid}$ than for $A_{s}$ and $B_{3 s l}$ because in the former the amounts of $\mathrm{Si}$ oxides are comparable to $\mathrm{Al}$ oxides.

In highly-weathered soils, kaolinites present low crystallinity (Ker, 1997; Schaefer et al., 2008), and $R_{B}$ and $R_{F}$ indexes for kaolinite and halloysite (Table 2 and Table 5) show that the overestimated values of Si oxides in the clay and silt fractions were due to the fact that the Rietveld Method was carried out taking into consider- 
ation the ideal stoichiometry and crystalline structure of kaolinite. MS results comparison (Table 9) and $R_{B}$ and $\mathrm{R}_{\mathrm{F}}$ indexes (Table 2 and Table 5) for the hematite and goethite indicate that the partial agreement of $\mathrm{Al}$ oxides values as well as $\mathrm{Fe}$ oxides values may be associated to very common Al-substitution in goethite and hematite in highly-weathered soils (Ker, 1997; Schaefer et al., 2008). Ti oxides are also common in highly-weathered soil, mainly anatase (Ker, 1997; Schaefer et al., 2008), nevertheless the soil under study presents rutile and the values overestimated for the clay fraction and underestimated for silt fraction were, probably, also due to considering the ideal stoichiometry and crystalline structure of rutile.

Rietveld Method results for the fine sand fractions (Figure 6 and Table 7) indicated a great amount of quartz. These results are in agreement with the ICP-AES data (Table 6) and IR spectra for $\mathrm{A}_{\mathrm{fs}}$ (Figure 7), $\mathrm{AB}_{\mathrm{fs}}$ and $B_{3 f 5}$. However, the amount of $\mathrm{Si}$ oxide is smaller, and the amount of $\mathrm{Al}$ oxide is larger in the sample $\mathrm{A}_{\mathrm{fs}}$ than $\mathrm{AB}_{\mathrm{fs}}$ and $\mathrm{B}_{3 \mathrm{fs}}$. Therefore the kaolinite-serpentine group and gibbsite bands intensities and regions are sharper for $A_{f s}$ (Figure 7).

In accordance with $\mathrm{Si}$ oxides abundance (Table 3) found by XRF and IR spectra (Figure 9), the Rietveld Method results for the coarse sand fractions (Figure 8 and Table 7) also indicate a greater amount of quartz. However, $\mathrm{AB}_{\mathrm{cs}}$ sample presented a larger amount of $\mathrm{Al}$ oxide than $A_{c s}$ and $B_{3 c s}$ (Table 3), and the IR spectra are different only in intensity.

For fine sand and coarse sand fractions, it was neither possible to quantify by the Rietveld Method the minerals of the kaolinite-serpentine group and gibbsite nor hematite, goethite and rutile because the Rietveld refinement did not present good numerical criteria when these minerals were included in the refinement, due to the fact that these phases might be not well crystallized. Nevertheless it was possible to identify and to confirm them qualitatively.

\section{Conclusions}

The Rietveld Method constituted a suitable quantitative mineralogical method for the characterization of an Acric Ferralsol and revealed that the clay fraction of all horizons is rich in gibbsite, besides minerals of the kaolinite-serpentine group and significant amounts of goethite. In the fine and coarse sand fractions there is quartz predominance. The silt fraction of the most superficial horizon presented a significant differentiation in relation to the same fraction of deeper horizons. Quartz, gibbsite, kaolinite, halloysite and goethite exist in comparable amounts in the A horizon, and quartz in great amounts in deeper horizons. Nevertheless, the values of the relative standard deviations of the mineral composition obtained using the Rietveld Method were consistently smaller for the more abundant phases and larger for the lesser abundant ones, and the mineralogical quantification of the finer fractions (clay and silt) by the Rietveld Method was successful.

\section{Acknowledgements}

The authors are thankful to CAPES, CNPq, and (FAPESP), and to Prof. Neyde Fabíola Balarezo Giarola, UEPG/Depto. de Ciência do Solo e Engenharia Agrícola for constructive comments on the manuscript, and to Mr. José Geraldo Catarino and Mr. José Augusto Lopes da Rocha for their help during XRD data collections in the Crystallography Laboratory of in the Instituto de Física de São Carlos Universidade de São Paulo, and to Mr. René de Oste for his assistance in the laboratories of Embrapa Instrumentação Agropecuária.

\section{References}

Abreu Jr., C.H.; Muraoka, T.; Lavorante, A.F. 2003. Relationship between acidity and chemical properties of Brazilian soils. Scientia Agricola 60: 337-343.

Alves, M.E.; Mascarenhas, Y.P.; French, D.H.; Vaz, C.P.M. 2007. Rietveld-based mineralogical quantification of deferried oxisol clays. Australian Journal of Soil Research 45: 224-232.

Alves, M.E.; Mascarenhas, Y.P.; Vaz, C.M.P. 2008. Comparison of procedures for quantification of kaolinite and gibbsite in ironfree clay in Latosols. Revista Brasileira de Ciência do Solo 32: 569-577. (in Portuguese, with abstract in English).

Berquó, T.S.; Thompson, R.; Partiti, C.S.M. 2004. Magnetic study of Brazilian peats from São Paulo state. Geoderma 118: 233-243.

Bish, D.L. 1994. Quantitative X-ray diffraction analysis of soils. p. 267-295. In: Amonette, J.E.; Zelazny, L.W.; Luxmoore, R.J., eds. Quantitative methods in soil mineralogy. Soil Science Society of America, Madison, WI, USA.

Bish, D.L.; Howard, S.A. 1988. Quantitative phase analysis using the Rietveld Method. Journal of Applied Crystallography 21: 86-91.

Bish, D.L.; von Dreele, R.B. 1989. Rietveld refinement of nonhydrogen atomic positions in kaolinite. Clays and Clay Minerals 37: 289-296.

Brown, G. 1980. Associated minerals. p. 361-410. In: Brindley, G.W.; Brown, G., eds. Crystal structures of clay minerals and their X-ray identification. Mineralogical Society, London, UK.

Brown, G.; Brindley, G.W. 1980. X-ray Diffraction procedures for clay mineral identification. p. 305-360. In: Brindley, G.W.; Brown, G., eds. Crystal structures of clay minerals and their Xray identification. Mineralogical Society, London, UK.

Caglioti, G.; Paoletti, A.; Ricci, F.P. 1958. Choice of collimators for a crystal spectrometer for neutron diffraction. Nuclear Instruments and Methods 3: 223-228.

Christensen, B.T. 1992. Physical fractionation of soil and organic matter in primary particle size and density separates. Advances in Soil Science 20: 1-19.

Corrêa, M.M.; Ker, J.C.; Barrón, V.; Torrent, J.; Fontes, M.P.F.; Curi, N. 2008. Crystallographic properties of kaolinite soils from coastal tablelands: the Amazon and the great bay "Reconcavo Baiano". Revista Brasileira de Ciência do Solo 32: 1857-1872. (in Portuguese, with abstract in English).

Curi, N.; Motta, P.E.F.; Fabris, J.D.; Oliveira, L.C.A. 2008. Mössbauer spectroscopy in the characterization of ferrous compounds in soils and its relationship with phosphorus retention. Química Nova 31: 1467-1471. (in Portuguese, with abstract in English).

Empresa Brasileira de Pesquisa Agropecuária [EMBRAPA]. 1997. Manual of Methods of Soil Analysis. 2. ed Embrapa/CNPS, Rio de Janeiro, RJ, Brazil. (in Portuguese).

Empresa Brasileira de Pesquisa Agropecuária [EMBRAPA]. 1999. Brazilian Soil Classification System. Embrapa Informação Tecnológica, Brasília, DF, Brazil. (in Portuguese). 
Fadigas, F.S.; Amaral-Sobrinho, N.M.B.; Mazur, N.; Anjos, L.H.C.; Freixo, A.A. 2002. Natural contents of heavy metals in some Brazilian soils classes. Bragantia 61: 151-159. (in Portuguese, with abstract in English).

Food and Agriculture Organization of the United Nations [FAO] 1994. Revised Legend With Ccorrections. FAO, Rome: Italy. (World Resources Report, 60).

Gadsden, J.A. 1975. Infrared Spectra of Minerals and Related Inorganic Compounds. Butterworths, Chichester, UK.

Giarola, N.F.B.; Lima, H.V.; Romero, R.E.; Brinatti, A.M.; Silva, A.P. 2009. Crystallography and mineralogy of the clay fraction of hardsetting horizons in soils of coastal tablelands in Brazil. Revista Brasileira de Ciência do Solo 33: 33-40. (in Portuguese, with abstract in English).

Gonçalves, D.; Leite, W.C.; Brinatti, A.M.; Saab, S.C.; Iarosz, K.C.; Mascarenhas, Y.P.; Carneiro, P.I.B.; Rosa, J.A. 2008. Mineralogy of Red Latosol under different management systems for twenty-four years. Revista Brasileira de Ciência do Solo 32: 2647-2652. (in Portuguese, with abstract in English).

Hazemann, J.L.; Berar, J.F.; Manceau, A. 1991. Rietveld studies of the aluminium-iron substituition in synthetic goethite. Materials Science Forum 79: 821-826.

Hill, R.J.; Howard, C.J. 1987. Quantitative phase analysis from neutron powder diffraction data using the Rietveld Method. Journal of Applied Crystallography 20: 467-474.

Hill, R.J.; Madsen, I.C. 2006. Sample preparation, instrument selection and data collection. p. 98-117. In: David, W.I.F.; Shankland, K.; McCusker, L.B.; Baerlocher, C.H., eds. Structure determination from powder diffraction data. Oxford University Press, Oxford, UK.

Howard, C.J.; Sabine, T.M.; Dickson, F. 1991. Structural and thermal parameters for rutile and anatase. Acta Crystallographica 47B: 462-468.

Janasi, V.A.; Andrade, S.; Ulbrich, H.H.G.J. 1995. The correction of instrumental drift in ICP-AES with sequential spectrometer and analysis of major, minor and trace elements in rocks. Boletim do Instituto Geológico da Universidade de São Paulo, Série Científica. 26: 45-58. (in Portuguese, with abstract in English).

Jones, R.C.; Babcoc, C.J.; Knowlton, W.B. 2000. Estimation of the total amorphous content of Hawai'I soils by the Rietveld Method. Soil Science Society of America Journal 64: 1100-1108.

Ker, J.C. 1997. Latosols from Brazil: a review. Geonomos 5: 17-40. (in Portuguese, with abstract in English).

Mehmel, M. 1935. Ueber die struktur von halloysit und metahalloysit. Zeitschrift fur Kristalographie 90: 35-43.

Moore, D.M.; Reynolds, R.C. 1989. X-ray Diffraction and the Identification and Analysis of Clay Minerals. Oxford University Press, New York, NY, USA.

Mori, P.E.; Reeves, S.; Correia, C.T.; Haukka, M. 1999. Development of a fused glass disc XRF facility and comparison with the pressed powder pellet technique at Instituto de Geociências, São Paulo University. Revista Brasileira de Geociências 29: 441-446.

Oliveira, S.M.B.; Imbernon, R.A.L.; Partiti, C.S.M.; Rechenberg, H.R. 1996. Mössbauer spectroscopy study of iron oxides and oxyhydroxides in gossans. Geoderma 73: 245-256.

Otero, X.L.; Ferreira, T.O.; Huerta-Díaz, M.A.; Partiti, C.S.M.; Souza Jr., V.; Vidal-Torrado, P.; Macías, F. 2009. Geochemistry of iron and manganese in soils and sediments of a mangrove system, island of Pai Matos (Cananéia-SP, Brazil). Geoderma 148: 318-335.
Pérez, M.G; Martin-Neto, L.; Saab, S.C.; Novotny, E. H.; Milori, D.M. B. P.; Bagnato, V. S.; Colnago, L.A.; Melo, W.J.; Knicker, H. 2004. Characterization of humic acids from a Brazilian Oxisol under different tillage systems by EPR, ${ }^{13} \mathrm{C}$ NMR, FTIR and fluorescence spectroscopy. Geoderma 118: 181-190.

Rietveld, H.M. 1967. Line profiles of neutron powder-diffraction peaks for structure refinement. Acta Crystallographica 22: 151152.

Rietveld, H.M. 1969. A profile refinement method for nuclear and magnetic structures. Journal of Applied Crystallography 2: 6571.

Russel, J.D. 1987. Infrared Methods. In: Wilson, M.J. A handbook of determinative methods in clay mineralogy. p. 133-173. Blackie, Glasgow, UK

Saalfeld, H.; Wedde, M. 1974. Refinement of the crystal structure of gibbsite, $\mathrm{Al}(\mathrm{OH})_{3}$. Zeitschrift fur Kristalographie 139: 129135.

Sabine, T.M.; Howard, C.J. 1982. Determination of the oxygen $x$ parameter in rutile by neutron powder methods. Acta Crystallographica 38B: 701-702.

Schaefer, C. E. G. R.; Fabris, J. D.; Ker, J.C. 2008. Minerals in the clay fraction of Brazilian Latosols (Oxisols): a review. Clay Minerals 43: 137-154.

Silva, L.B.; Dick, D.P.; Inda Jr, A.V. 2008. Highland subtropical soils: chemical attributes, content of organic matter and its resistance to chemical oxidation. Ciência Rural 38: 1167-1171. (in Portuguese, with abstract in English).

Tanner, C.B.; Jackson, M.L. 1947. Nomographs of sedimentation times for soil particles under gravity or centrifugal acceleration. Soil Science Society of America Proceedings 12: 60-65.

Tsirel'son, V.G.; Antipin, M.Y.; Strel'tsov, V.A.; Ozerov, R.P.; Struchkov, Y.T. 1988. Electron density distribution and electric field gradient in hematite at $153 \mathrm{~K}$ determined from precision X-ray diffraction data. Soviet Physics Doklady 33: 89-91.

Viana, J.H.M.; Couceiro, P.R.C.; Pereira, M.C.; Fabris, J.D.; Fernandes Filho, E.I.; Schaefer, C.E.G.R.; Rechenberg, H.R.; Abrahão, W.A.P.; Mantovani, E.C. 2006. Occurrence of magnetite in the sand fraction of an Oxisol in the Brazilian savanna ecosystem, developed from a magnetite-free lithology. Australian Journal of Soil Research 44: 71-83.

Will, G.; Bellotto, M.; Parrish, W.; Hart, M. 1988. Crystal structures of quartz and magnesium germanate by profile analysis of synchroton-radiation high-resolution powder data. Journal of Applied Crystallography 21: 182-191.

Young, R.A. 1995. DBWS-9411: an upgrade of the DBWS programs for Rietveld refinement with PC and mainframe computers. Journal of Applied Crystallography 28: 336-367.

Young, R.A. 2002. The Rietveld Method. International Union of Crystallography, Oxford University Press, New York, NY. USA.

Young, R.A.; Larson, A.C.; Paiva-Santos, C.O. 2000. User's guide to program DBWS-9807a for Rietveld analysis of X-ray and neutron powder diffraction patterns. Georgia Institute of Technology, Atlanta, GA, USA.

Received January 06, 2009

Accepted February 24, 2010 